\title{
Effects of Aqueous Ammonia Vapor on the Color and Chemical Structure of Robinia pseudoacacia and Oak Woods
}

\author{
Agata Stachowiak-Wencek, ${ }^{\mathrm{a}, *}$ Monika Bartkowiak, ${ }^{\mathrm{a}}$ Magdalena Zborowska, ${ }^{\mathrm{a}}$ and \\ Jan Bocianowski ${ }^{\text {b }}$
}

\begin{abstract}
Aqueous ammonia vapors were found to affect the color and structure of oak (Quercus L.) and Robinia pseudoacacia L. woods. The modification process was performed using $5 \%$ or $10 \%$ ammonia concentration at a temperature of $120^{\circ} \mathrm{C}, 130^{\circ} \mathrm{C}$, or $140^{\circ} \mathrm{C}$. Wood mass and volume change coefficients were determined. The degree of wood discoloration was determined using the Commission Internationale de l'Eclairage (CIE) Lab system, and the changes to the chemical structure were determined using the Fourier transform infrared (FTIR) technique. The samples darkened due to the modification. They also became less red and less yellow. It was found that Robinia wood was more discolored. The total color change $\left(\Delta E^{*}\right)$ of Robinia wood ranged from 39.0 to 41.9 , and of oak wood ranged from 26.8 to 33.3. The $L^{*}$ and $b^{*}$ color coordinates had a significant effect on the $\Delta E$. Analysis of variance showed that in most cases both the concentration of the aqueous ammonia solution and the process temperature alone did not cause significant differences in the colour of the wood (GenStat 18ed (VSN International 2015)). However, the interaction between concentration and temperature was important. Analysis of wood structure via FTIR showed that during the applied treatment, wood underwent chemical changes and that the effects were different in the compared species.
\end{abstract}

Keywords: Ammonia treatment; Oak; Robinia pseudoacacia; CIE $L^{*} a * b *$ system; FTIR

Contact information: a: Institute of Chemical Wood Technology, Poznan University of Life Sciences, PL60637 Poznan, Poland; b: Department of Mathematical and Statistical Methods, Poznan University of Life Sciences, PL-60637 Poznan, Poland; *Corresponding author: agata.stachowiak@up.poznan.pl

\section{INTRODUCTION}

The growing demand for products made of natural materials is one of the components of changes taking place in the modern consumption model. Currently, wood is a popular material for use in interior design. Both the color of the wood and its pattern are parameters that influence consumer preferences.

Wood colour alters itself as time passes, which is often an undesirable phenomenon. Colour changes stemming from the passage of time are caused by sunlight, temperature, and humidity. According to the literature, they are related to alterations that occur under the influence of the variables in wood chemical composition. Almost every wood component is susceptible to sunlight. Lignin absorbs ultraviolet (UV) light to an extreme degree (approximately 80 to 95\%) and undergoes numerous photochemical reactions due to sunlight exposure.

Natural wood colour can be enhanced by differentiated technological treatments, such as colourant applications to its surfaces, or thermal and chemical modifications to the 
wood. The crucial difference between these methods is the discolouration depth. Colourants merely discolour the wood's external layers. However, both chemical and thermal modifications lead to colour alternations in all of the cross-sections.

Wood treatment with ammonia has been known since the early $20^{\text {th }}$ century. Recently, scientific centres and the wood industry have become interested in wood discolouration methods via ammonia (Weigl et al. 2009, 2012; Čermák and Dejmal 2013; Šprdlík et al. 2016). After modification with ammonia, wood becomes darker and could replace exotic-coloured wood species (Weigl et al. 2012; Timar et al. 2016; Machová et al. 2019). Treating oak wood with ammonia can also result in a 'subfossil oak' effect, a highly valued material that is developed in nature over thousands of years (Kolár and Rybníček 2010; Mańkowski et al. 2016).

There are three known methods of wood treatment with ammonia: soaking or boiling it in ammonia-water solution, treating wood with gaseous ammonia, and treating wood with a mixture of water vapour and ammonia gas. Initially, the most frequently modified wood species was oak (Weigl et al. 2009) due to its high tannin content, which is considered to be the most susceptible component to ammonia. Tannins contribute to the discoloration of wood (Tinkler 1921; Čermák and Dejmal 2013; Pařil et al. 2014). Further research showed that ammonia can discolour many other wood species. During experiments to modify deciduous and coniferous woods, better colouring effects were always observed with deciduous wood species (Weigl et al. 2007, 2009; Miklečić et al. 2012).

According to the literature, wood treatment with ammonia leads to chemical and anatomical structure alterations. Šprdlík et al. (2016) suggested that there were changes in the lumen, cell wall deformation, and swelling in the middle lamella, primary cell walls, and secondary cell walls. Rosca et al. (2002) stated that ammonia has a relatively high affinity to the main wood components. It can cause changes to lignin and carbohydrate complexes, permeate into crystalline cellulose structures, increase the nitrogen content, increase the number of amine bonds, and decrease the number of ester bonds. However, it does not appreciably change cellulose, hemicellulose, and lignin contents. The described alterations result from soaking wood in pure ammonia or ammonia solutions. Ammonia, when in a gaseous state, influences wood tissues to a considerably smaller extent.

The changes to wood chemical and anatomical structure affect its physical and mechanical properties. Wood plasticity is enhanced due to ammonia treatment (Minelga et al. 2013), as well as its dimensional stability in the radial direction; however, its stability in the tangential direction decreases (Weigl et al. 2009). Equilibrium moisture content (EMC) evolves remarkably (Weigl et al. 2009, 2012; Čermak and Dejmal 2013). Alterations in the modulus of elasticity (MOE) depend on the wood species. Weigl et al. (2012) observed MOE changes solely for oak wood; the authors did not observe such effects in the pine and the spruce. Čermak and Dejmal (2013) confirmed the lack of appreciable MOE changes. The increase in MOE due to ammonia treatment of compressed wood, called lignamon, was reported by Rousek et al. (2015). There was a decrease in sample endurance properties following modifications with ammonia and the stiffness ranged from 6 to 15\%, which is not crucial as far as common wood applications are concerned according to Čermak and Dejmal (2013). Ammonia leads to the enhancement of wood to water affinity and also to in anisotropic shrinkage and swelling (Weigl et al. 2009; Čermak and Dejmal 2013). Appreciable changes in wood density have not been detected in any examined species (Weigl et al. 2012). 
Čermák and Dejmal (2013) claimed that discolouration effects obtained by means of thermal and ammonia treatment were similar. Nevertheless, the thermal treatment caused more substantial alterations in the material's chemical structure that contributed to the deterioration of mechanical properties to a greater extent (Čermák and Dejmal 2013; Kučerová et al. 2016).

The majority of available information on the alterations of wood chemical structure and properties resulted from an ammonia treatment that focuses on soaking or boiling wood in an ammonia-water solution as well as treating the wood with gaseous ammonia. There have been only a few reports on ammonia's influence as a vapors of an aqueous ammonia solution, and such reports are fragmented. The aim of this paper is to determine the alterations in wood colour caused by wood treatment with a mixture of water vapour and ammonia gas, as well as to determine chemical structure changes that occurred in wood as a result of such treatments.

\section{EXPERIMENTAL}

\section{Materials}

The investigated wood materials were Robinia pseudoacacia L. and oak (Quercus L.) (State Forests, Poland). Samples with the dimensions of $15 \mathrm{~mm} \times 30 \mathrm{~mm} \times 20 \mathrm{~mm}( \pm$ $1 \mathrm{~mm}$ ) (longitudinal $\times$ tangential $\times$ radial) were prepared from the same board. The test samples were polished with sandpaper $(400 \mathrm{P})$ prior to the investigation. The investigations were performed using three samples from each variant. The moisture content of the samples subjected to modification was at the level of $6.2 \% \pm 0.1 \%$. After the modification process it was from 15.3 to $16.5 \%$. Samples after modification were conditioned for $48 \mathrm{~h}$ under normal conditions (i.e. temperature $20 \pm 2{ }^{\circ} \mathrm{C}$, relative humidity $65 \pm 5 \%$ ). After this time, tests were carried out on the color of the samples, in which the moisture content was in the range of 9.5 to $10.4 \%$.

The density of Robinia wood samples used in the study (before modification) was from 821 to $856 \mathrm{~kg} / \mathrm{m}^{3}$, and oak wood from 746 to $756 \mathrm{~kg} / \mathrm{m}^{3}$.

\section{Methods}

\section{Ammonia modification}

The modification process was conducted according to the instructions shown in the description of patent PL 195348 B1 (Zakrzewski (2007). This included a gasproof laboratory chamber equipped with stub tubes that enabled a desirable medium to enter it and allowed for removal of vaporous and gaseous post-reaction products. The modification process was carried out in an atmosphere of aqueous ammonia vapors. The concentration of dosed ammonia during the modification process was constant, $5 \%$ or $10 \%$. An aqueous solution of ammonia at the assumed concentration was prepared before feeding it into the chamber in which the modification process was carried out. Then the prepared ammonia solution was fed to the steam generator. In the steam generator, the solution was heated, maintaining the boiling point. The vapors of an aqueous ammonia solution, which were produced in the generator, were directed to a gas-tight chamber. In order to prevent condensation during modification, the chamber was kept at a temperature above the boiling point of the medium.

The entire modification process took $24 \mathrm{~h}$. For the first $6 \mathrm{~h}$, wood was treated (simultaneously) with vapors of an aqueous ammonia and temperature. For the remaining 
$18 \mathrm{~h}$, the wood was placed in a chamber in which the assumed temperature was maintained without dosing the vapors of an aqueous ammonia solution. This was to maintain the conditions that allow the reaction between the ammonia that has penetrated in the wood and the phenolic extractives contained in the wood.

The modification process was carried out at three temperatures, i.e. $120{ }^{\circ} \mathrm{C}, 130{ }^{\circ} \mathrm{C}$ and $140{ }^{\circ} \mathrm{C}$, to check their effect on the degree of wood discoloration. The possibility of lowering the process temperature from $140{ }^{\circ} \mathrm{C}$ to $120{ }^{\circ} \mathrm{C}$, as well as concentrations from $10 \%$ to $5 \%$ ammonia can be of significant economic importance. In industrial conditions, it is strived to achieve varying degrees of wood discoloration, i.e. from lighter to darker. The use of various variants of both temperature and ammonia concentration was intended to answer the above issues.

The density of wood before and after the modification process was determined as the ratio of mass to volume of wood.

The effect of the wood modification process was assessed based on the mass change factor $\left(Z_{\mathrm{M}}, \%\right)$ and the volume change factor $\left(Z_{\mathrm{V}}, \%\right)$. Mass and volume change factors were calculated according to Eqs. 1 and 2,

$$
\begin{aligned}
& Z_{M}=\frac{M_{1}-M_{2}}{M_{1}} \times 100 \\
& Z_{\mathrm{V}}=\frac{V_{1}-V_{2}}{V_{1}} \times 100
\end{aligned}
$$

where $M_{1}$ is the unmodified wood mass completely dry $(\mathrm{g}), M_{2}$ is the modified wood mass completely dry $(\mathrm{g}), V_{1}$ is the unmodified wood sample volume $\left(\mathrm{cm}^{3}\right)$, and $V_{2}$ is the modified wood sample volume $\left(\mathrm{cm}^{3}\right)$.

\section{Colour measurements}

All the colour measurements were taken from the radial surfaces of the samples. The samples (control and treatment with vapous of ammonia solutions) were measured before and after modification. The Commision Internationale de l'Eclairage (CIE) color coordinates $\left(L^{*}, a^{*}\right.$, and $\left.b^{*}\right)$ were recorded using a Datacolour 600 dual-beam $\mathrm{d} / 8^{\circ}$ spectrophotometer (Lorentzen \& Wettre, Kista, Sweden). A part used the $\mathrm{D}_{65}$ standard illuminant and the wavelength range was from $360 \mathrm{~nm}$ to $700 \mathrm{~nm}$. The maximum reflection of instrument was 0.15 and the mean 0.08 . The diameter of the sensor head was $10 \mathrm{~mm}$. The tests were performed on three samples for each variant. Three fixed location points were measured on each sample. The spectrophotometer calibration was performed using three standards: white plate, green plate, and black trap.

Data listed in this work are the average of nine replicated measurements. The colour sphere with axes of $L^{*}, a^{*}$, and $b^{*}$ are described as a trisimulus system of colour coordinates. The total colour change in the CIE $L^{*} a^{*} b^{*}$ system was calculated according to Eq. 3,

$$
\Delta E^{*}=\sqrt{\left(\Delta L^{*}\right)^{2}+\left(\Delta a^{*}\right)^{2}+\left(\Delta b^{*}\right)^{2}}
$$

where $\Delta E^{*}$ is the total colour change, $L^{*}$ is the achromatic coordinate or luminosity (axis value ranges from 0 to 100 where 100 means a given colour that is close to white, and 0 means a colour that is close to black), and $a^{*}$ and $b^{*}$ are the chromatic coordinates. Axis $a^{*}$ depicts green $\left(a^{*}<0\right)$ or red $\left(a^{*}>0\right)$ colour, and axis $b^{*}$ depicts blue $\left(b^{*}<0\right)$ or yellow $\left(b^{*}>0\right)$ colour. The $C^{*}$ parameter (Table 1) expresses chroma and determines the 'colour purity,' whereas $h$ (hue) is the colour angle $\left(0^{\circ}\right.$ represents red colour on $+a^{*}$ axis, $90^{\circ}$ 
represents yellow on $+b^{*}$ axis, $180^{\circ}$ represents green on $-a^{*}$ axis, and $270^{\circ}$ represents blue on $-b^{*}$ axis). The $\Delta L^{*}$ value expresses the luminosity difference, the $\Delta a^{*}$ expresses the difference on the $a^{*}$ axis (red to green), and the $\Delta b^{*}$ expresses the difference on the $\mathrm{b}^{*}$ axis (yellow to blue).

\section{Fourier transform infrared (FTIR) measurement}

The control samples and samples after treatment with vapous of ammonia solutions were analysed using an Alpha FTIR spectrometer produced by Brüker Optics GmbH (Ettlingen, Germany). This spectrophotometer was equipped with an attenuated total reflectance (ATR) with a germanium crystal accessory (Brüker, Ettlingen, Germany). The spectral range between $4000 \mathrm{~cm}^{-1}$ and $600 \mathrm{~cm}^{-1}$ was measured. The spectral resolution of the spectrophotometer was $4 \mathrm{~cm}^{-1}$. Each spectrum was computed as an average of 32 successive measurements to minimize the measurement error. Three measurements were performed on each sample. The bands in the FTIR spectra of the sample were assigned with the aid of data from the literature (Popescu et al. 2007; Xu et al. 2013; Lao et al. 2014).

\section{Statistical analysis}

The normal distributions of the study parameters were established using the Shapiro-Wilk normality test. For each species, a two-way analysis of variance (ANOVA) was conducted to study the effects of concentration, temperature, and concentrationtemperature interaction on the variability of $L^{*}, a^{*}, b^{*}, h, C^{*}, \Delta L^{*}, \Delta a^{*}, \Delta b^{*}$, and $\Delta E$. Tukey's least significant difference (LSD) test was used to determine the differences across concentration and temperature for all parameters. Duncan's tests were conducted for multiple comparisons of the means of the colour parameters at the different temperatures and concentrations for each wood species. Statistical analysis was based on GenStat 18ed (VSN International 2015).

\section{RESULTS AND DISCUSSION}

\section{Volume and Mass Measurements of Samples}

Table 1 shows the alternations in mass, volume and density for the samples that were hydrothermally modified in the ammonia atmosphere. Consequently, the Robinia wood samples changed their volume from -0.76 to $4.82 \%$, whereas the oak wood samples changed from 2.90 to $4.82 \%$. Almost all the samples increased their volume regardless of the modification conditions of the process. The exceptions were the Robinia wood samples treated with vapous of $10 \%$ ammonia water solutions at a temperature of $130{ }^{\circ} \mathrm{C}$, whose volume decreased. It is difficult to clearly explain the reason for the changes noted for Robinia wood. Probably the samples had an invisible anatomical defect that could have caused a different deformation of the material during modification than in other samples. Due to the modification, the investigated samples also increased their mass, which ranged from 5.68 to $8.18 \%$. Smaller mass changes were recorded for the Robinia samples (from 5.68 to $7.00 \%$ ) versus the oak samples (from 6.41 to $8.18 \%$ ). During wood modification, the temperature was an important process parameter. As the process temperature increased, the changes in sample mass and volume increased. The tendency was not observed during the treatment with the $10 \%$ mixture. Moreover, the oak wood behaved in a different manner than the Robinia wood. For the Robinia wood, the value changes of the two coefficients 
were the largest at the highest temperature of the process $\left(140^{\circ} \mathrm{C}\right)$. However, for the oak wood, the changes were the smallest at the same temperature of $140{ }^{\circ} \mathrm{C}$.

The Robinia wood density as a result of modifications varied from 2.4 to $6.3 \%$. The biggest change was recorded for wood modified with $10 \%$ ammonia at $130{ }^{\circ} \mathrm{C}$. In contrast, changes in oak wood density were less varied and ranged from 3.3 to $3.9 \%$.

Table 1. Values of Factors for Change of Mass and Volume of Samples

\begin{tabular}{|c|c|c|c|c|c|c|}
\hline $\begin{array}{l}\text { Wood } \\
\text { Species }\end{array}$ & \begin{tabular}{|c|} 
Ammonia \\
Concentration \\
$(\%)$
\end{tabular} & $\begin{array}{c}\text { Temperature } \\
\left({ }^{\circ} \mathrm{C}\right)\end{array}$ & $\begin{array}{c}\text { Mass } \\
\text { Change } \\
\text { Factor (\%) }\end{array}$ & $\begin{array}{c}\text { Volume } \\
\text { Change } \\
\text { Factor (\%) }\end{array}$ & $\begin{array}{l}\text { Density } \\
\text { before } \\
\mathrm{kg} / \mathrm{m}^{3}\end{array}$ & $\begin{array}{c}\text { Density } \\
\text { after } \\
\mathrm{kg} / \mathrm{m}^{3}\end{array}$ \\
\hline \multirow{2}{*}{ Robinia } & 5 & $\begin{array}{l}120 \\
130 \\
140\end{array}$ & $\begin{array}{l}5.68(0.03) \\
6.27(0.21) \\
6.90(0.16)\end{array}$ & $\begin{array}{l}3.02(0.54) \\
4.00(0.50) \\
4.82(0.37)\end{array}$ & $\begin{array}{l}821(5.42) \\
831(12.5) \\
834(14.5)\end{array}$ & $\begin{array}{l}799(2.26) \\
811(13.7) \\
808(15.8)\end{array}$ \\
\hline & 10 & $\begin{array}{l}120 \\
130 \\
140\end{array}$ & $\begin{array}{l}5.82(0.12) \\
5.72(0.14) \\
7.00(0.11)\end{array}$ & $\begin{array}{c}3.02(0.35) \\
-0.76(3.95) \\
4.01(0.12)\end{array}$ & $\begin{array}{l}843(16.7) \\
856(39.0) \\
821(4.86)\end{array}$ & $\begin{array}{l}818(17.4) \\
802(13.4) \\
795(4.72)\end{array}$ \\
\hline \multirow[b]{2}{*}{ Quercus } & 5 & $\begin{array}{l}120 \\
130 \\
140\end{array}$ & $\begin{array}{l}6.41(0.04) \\
7.44(0.14) \\
8.18(0.16)\end{array}$ & $\begin{array}{l}3.21(0.11) \\
3.90(0.27) \\
4.82(0.37)\end{array}$ & $\begin{array}{l}754(4.20) \\
756(4.54) \\
752(1.43)\end{array}$ & $\begin{array}{l}729(4.86) \\
728(1.55) \\
725(4.35)\end{array}$ \\
\hline & 10 & $\begin{array}{l}120 \\
130 \\
140\end{array}$ & $\begin{array}{l}6.69(0.04) \\
6.99(0.85) \\
6.68(0.57)\end{array}$ & $\begin{array}{l}2.96(0.48) \\
3.48(0.26) \\
2.90(1.87)\end{array}$ & $\begin{array}{l}750(22.6) \\
753(15.9) \\
746(18.6)\end{array}$ & $\begin{array}{l}721(25.1) \\
728(12.6) \\
717(16.6)\end{array}$ \\
\hline $\begin{array}{l}\text { Values } \\
\text { Density } \\
\text { Density }\end{array}$ & e standard de & $\begin{array}{l}\text { iation are in } \\
\text { nodification } \\
\text { dification }\end{array}$ & ntheses & & & \\
\hline
\end{tabular}

Table 2. Mean Squares from Two-way Analysis of Variance for Colour Coordinates for the Wood Species

\begin{tabular}{|c|c|c|c|c|c|}
\hline $\begin{array}{c}\text { Wood } \\
\text { Species }\end{array}$ & $\begin{array}{l}\text { Source of } \\
\text { Variation }\end{array}$ & Concentration & Temperature & $\begin{array}{c}\text { Concentration-temperature } \\
\text { Interaction }\end{array}$ & Residual \\
\hline & d.f. & 1 & 2 & 2 & 48 \\
\hline \multirow{9}{*}{ Robinia } & $L^{*}$ & 1.307 & 0.771 & $14.568^{* * *}$ & 1.701 \\
\hline & $a^{*}$ & 1.0251 & 0.921 & $3.123^{* \star *}$ & 0.339 \\
\hline & $b^{\star}$ & 3.593 & 0.88 & $12.925^{\star \star \star}$ & 1.548 \\
\hline & $h$ & 0.939 & $8.17^{*}$ & $7.356^{\star}$ & 1.686 \\
\hline & $C^{*}$ & 4.461 & 1.608 & $16.153^{\star \star *}$ & 1.842 \\
\hline & $\Delta L^{*}$ & 0.887 & 0.94 & $13.104^{* *}$ & 1.796 \\
\hline & $\Delta a^{*}$ & 0.957 & 0.979 & $3.009^{* * *}$ & 0.343 \\
\hline & $\Delta b^{*}$ & 2.806 & 1.123 & $11.912^{* *}$ & 1.604 \\
\hline & $\Delta E$ & 2.636 & 1.768 & $23.538^{* *}$ & 3.157 \\
\hline \multirow{9}{*}{ Quercus } & $L^{*}$ & 21.47 & 29.37 & $77.5^{\star \star}$ & 10.71 \\
\hline & $a^{*}$ & 0.4214 & $2.0295^{\star * *}$ & 0.0784 & 0.183 \\
\hline & $b^{\star}$ & 0.804 & 0.986 & $15.625^{\star *}$ & 2.579 \\
\hline & $h$ & $14.23^{*}$ & $60.692^{\star \star \star}$ & $33.774^{\star \star \star}$ & 3.175 \\
\hline & $C^{*}$ & 0.423 & 0.323 & $14.52^{\star \star}$ & 2.64 \\
\hline & $\Delta L^{*}$ & 21.45 & 29.38 & $77.53^{\star *}$ & 10.71 \\
\hline & $\Delta a^{*}$ & 0.4196 & $2.033^{\star \star \star}$ & 0.0783 & 0.183 \\
\hline & $\Delta b^{*}$ & 0.804 & 0.987 & $15.61^{* \star}$ & 2.577 \\
\hline & $\Delta E$ & 20.19 & 26.43 & $92.04^{* *}$ & 12.93 \\
\hline
\end{tabular}


Table 2 depicts the results from testing the general hypothesis, which shows the occurrence (or the lack) of statistical differences. The analysis of variance indicated that in the majority of cases neither the aqueous ammonia solution concentration itself nor the process temperature considerably changed the wood colour. The main effect of concentration was only statistically significant for $h$ for the oak. The main effect of temperature was vital for $h$ for the Robinia, and for $a^{*}, h$, and $\Delta a^{*}$ for the oak. The concentration-temperature interaction was significant for all the traits of the study, except for $a^{*}$ and $\Delta a^{*}$ for the oak.

\section{Colour Changes}

As a result of the modification, the wood has been discolored in its entire volume. This has practical significance both at the products production stage and during renovation works.

Table 3. Colour Parameters of the Robinia pseudoacacia and Quercus Wood Modified with Vapors of Ammonia Solutions

\begin{tabular}{|c|c|c|c|c|c|c|c|}
\hline \multirow[b]{2}{*}{$\begin{array}{l}\text { Wood } \\
\text { Species }\end{array}$} & \multicolumn{2}{|c|}{ Treatment Parameters } & \multicolumn{5}{|c|}{ Colour Coordinates } \\
\hline & $\begin{array}{c}\text { Temperature } \\
\left({ }^{\circ} \mathrm{C}\right)\end{array}$ & $\begin{array}{c}\text { Concentration } \\
(\%)\end{array}$ & \multirow{2}{*}{$\begin{array}{c}L^{*} \\
65.19 \\
(1.02)\end{array}$} & \multirow{2}{*}{$\begin{array}{c}a^{\star} \\
7.13 \\
(0.15)\end{array}$} & \multirow{2}{*}{$\begin{array}{c}\boldsymbol{b}^{\star} \\
24.49 \\
(0.54)\end{array}$} & \multirow{2}{*}{$\begin{array}{c}\boldsymbol{h}\left(^{\circ}\right) \\
73.72 \\
(0.96)\end{array}$} & \multirow{2}{*}{$\begin{array}{c}C^{\star} \\
25.53 \\
(0.69)\end{array}$} \\
\hline \multirow{7}{*}{ Robinia } & \multicolumn{2}{|c|}{ control } & & & & & \\
\hline & 120 & 5 & $\begin{array}{c}30.05 \\
(0.73)^{B C}\end{array}$ & $\begin{array}{c}3.76 \\
(0.42)^{A}\end{array}$ & $\begin{array}{c}6.21 \\
(0.72)^{B C}\end{array}$ & $\begin{array}{c}58.80 \\
(0.48)^{A}\end{array}$ & $\begin{array}{c}7.26 \\
(0.83)^{\mathrm{B}}\end{array}$ \\
\hline & 130 & 5 & $\begin{array}{c}30.94 \\
(1.71)^{A} \text { to } C\end{array}$ & $\begin{array}{c}4.30 \\
(0.79)^{A}\end{array}$ & $\begin{array}{c}7.09 \\
(1.67)^{\mathrm{BC}}\end{array}$ & $\begin{array}{c}58.51 \\
(1.50)^{A}\end{array}$ & $\begin{array}{c}8.30 \\
(1.84)^{\text {в }}\end{array}$ \\
\hline & 140 & 5 & $\begin{array}{c}32.12 \\
(1.29)^{A}\end{array}$ & $\begin{array}{c}5.04 \\
(0.57)^{A}\end{array}$ & $\begin{array}{c}8.32 \\
(1.33)^{A}\end{array}$ & $\begin{array}{c}58.66 \\
(1.28)^{A}\end{array}$ & $\begin{array}{c}9.74 \\
(1.43)^{A}\end{array}$ \\
\hline & 120 & 10 & $\begin{array}{c}31.24 \\
(0.98) A B\end{array}$ & $\begin{array}{c}4.27 \\
(0.41)^{A}\end{array}$ & $\begin{array}{c}7.22 \\
(0.96)^{A B}\end{array}$ & $\begin{array}{c}59.45 \\
(1.02)^{\mathrm{A}}\end{array}$ & $\begin{array}{c}8.42 \\
(1.02)^{\mathrm{B}}\end{array}$ \\
\hline & 130 & 10 & $\begin{array}{c}31.12 \\
(1.89) A B\end{array}$ & $\begin{array}{c}4.12 \\
(0.77)^{\mathrm{A}}\end{array}$ & $\begin{array}{c}6.88 \\
(1.68)^{\mathrm{BC}}\end{array}$ & $\begin{array}{c}58.79 \\
(1.93)^{A}\end{array}$ & $\begin{array}{c}8.02 \\
(1.82)^{\mathrm{B}}\end{array}$ \\
\hline & 140 & 10 & $\begin{array}{c}29.82 \\
(0.75)^{c}\end{array}$ & $\begin{array}{c}3.89 \\
(0.37)^{A}\end{array}$ & $\begin{array}{c}5.98 \\
(0.69) \mathrm{C}\end{array}$ & $\begin{array}{c}56.94 \\
(1.11)^{\mathrm{B}}\end{array}$ & $\begin{array}{c}7.14 \\
(0.78)^{\text {в }}\end{array}$ \\
\hline LSD $_{0.05}$ & & & 1.24 & 3.89 & 1.18 & 1.23 & 1.29 \\
\hline \multirow{7}{*}{ Quercus } & \multicolumn{2}{|c|}{ control } & $\begin{array}{l}66.80 \\
(1.40)\end{array}$ & $\begin{array}{c}7.12 \\
(0.55)\end{array}$ & $\begin{array}{l}22.95 \\
(1.54)\end{array}$ & $\begin{array}{l}72.78 \\
(2.94)\end{array}$ & $\begin{array}{l}24.04 \\
(0.46)\end{array}$ \\
\hline & 120 & 5 & $\begin{array}{c}35.34 \\
(0.74)^{\mathrm{B}} \\
\end{array}$ & $\begin{array}{c}3.53 \\
(0.28) \mathrm{BC}\end{array}$ & $\begin{array}{c}8.49 \\
(0.69)^{\mathrm{C}}\end{array}$ & $\begin{array}{c}67.44 \\
(1.12) \mathrm{BC}\end{array}$ & $\begin{array}{c}9.20 \\
(0.73)^{\mathrm{C}}\end{array}$ \\
\hline & 130 & 5 & $\begin{array}{c}37.48 \\
(1.76)^{\mathrm{B}} \\
\end{array}$ & $\begin{array}{c}4.08 \\
(0.36)^{A} \\
\end{array}$ & $\begin{array}{c}10.12 \\
(1.31) A B\end{array}$ & $\begin{array}{c}67.91 \\
(1.39)^{\mathrm{B}}\end{array}$ & $\begin{array}{c}10.91 \\
(1.33) \mathrm{AB}\end{array}$ \\
\hline & 140 & 5 & $\begin{array}{c}36.17 \\
(1.17)^{\mathrm{B}} \\
\end{array}$ & $\begin{array}{c}4.30 \\
(0.25)^{A}\end{array}$ & $\begin{array}{c}9.54 \\
(0.77)^{A \text { to } C}\end{array}$ & $\begin{array}{c}65.69 \\
(0.83)^{D}\end{array}$ & $\begin{array}{c}10.47 \\
(0.79)^{A \text { to } ~}\end{array}$ \\
\hline & 120 & 10 & $\begin{array}{c}41.37 \\
(7.36)^{A}\end{array}$ & $\begin{array}{c}3.49 \\
(0.38) \mathrm{C}\end{array}$ & $\begin{array}{c}10.87 \\
(3.07)^{A}\end{array}$ & $\begin{array}{c}71.51 \\
(3.39)^{A}\end{array}$ & $\begin{array}{c}11.44 \\
(3.01)^{A}\end{array}$ \\
\hline & 130 & 10 & $\begin{array}{c}35.89 \\
(1.80)^{\mathrm{B}}\end{array}$ & $\begin{array}{c}3.90 \\
(0.43)^{A B}\end{array}$ & $\begin{array}{c}9.07 \\
(1.28) \mathrm{BC}\end{array}$ & $\begin{array}{c}66.66 \\
(0.95)^{B} \text { to } D\end{array}$ & $\begin{array}{c}9.87 \\
(1.34)^{\mathrm{BC}}\end{array}$ \\
\hline & 140 & 10 & $\begin{array}{c}35.52 \\
(1.38)^{B}\end{array}$ & $\begin{array}{c}4.00 \\
(0.70)^{A}\end{array}$ & $\begin{array}{c}8.94 \\
(1.29)^{B C}\end{array}$ & $\begin{array}{c}65.96 \\
(1.66) \mathrm{CD}\end{array}$ & $\begin{array}{c}9.80 \\
(1.44)^{\mathrm{BC}}\end{array}$ \\
\hline $\mathrm{LSD}_{0.05}$ & & & 3.1 & 0.4 & 1.52 & 1.69 & 1.54 \\
\hline
\end{tabular}


Table 3 presents the mean values of $L^{*}, a^{*}, b^{*}, h$, and $C^{*}$ parameters, the standard deviations, and the $95 \%$ confidence intervals (significance level of 0.05 ), based on a $t$ distribution that were calculated with the assumption of the normal distribution.

The $L^{*}$ coordinate value following the ammonia modification decreased from 65.2 to the range 29.8 to 32.1 for the Robinia wood, whereas for the oak wood, it decreased from 66.8 to the range 35.3 to 41.4 . This was because the ammonia solution vapours treatment caused the surfaces of all samples to darken considerably. For the samples treated with a 5\% aqueous ammonia solution, the sample colour became darker along with an increase in process temperature. However, for the samples treated with $10 \%$ aqueous ammonia solution, the tendency was reversed; as the temperature rose, the samples became lighter in colour. The Robinia wood obtained the darkest colour after being modified with $10 \%$ aqueous ammonia solution at a temperature of $140{ }^{\circ} \mathrm{C}$, and the oak wood became the darkest after modification with $5 \%$ solution at a temperature of $120{ }^{\circ} \mathrm{C}$. However, the Robinia wood obtained the lightest colour after the modification with $5 \%$ aqueous ammonia solution at a temperature of $140{ }^{\circ} \mathrm{C}$, and the oak wood became the lightest after the modification with $10 \%$ solution at a temperature of $120{ }^{\circ} \mathrm{C}$. Significant sample darkening was also reported by Miklečić et al. (2012). The $L^{*}$ parameter for oak wood as reported by Miklečić et al. (2012) was at the level of 60.9 prior the process treatment and 35.5 afterwards. For maple, spruce, and larch, the $L^{*}$ value decreased from values of 66.7 to 83.3 to values of 39.9 to 70.0 .

The chromatic coordinates of $a^{*}$ and $b^{*}$ also underwent a substantial change following the modification with ammonia. The value of the $a^{*}$ coordinate for the Robinia wood decreased from 7.1 to the range 3.8 to 5.0, and from 7.1 to the range 3.49 to 4.30 for oak wood. The value of the $b^{*}$ coordinate dropped to a greater extent. For the Robinia, it decreased from 24.5 to approximately 6.0 to 8.3 , and for the oak, it decreased from 23.0 to the range 8.5 to 10.9 . The recorded $a^{*}$ and $b^{*}$ changes indicated that the wood following the treatment with ammonia became less red and less yellow. The tendency of $a^{*}$ and $b^{*}$ chromatic changes was similar to the changes to the $L^{*}$ coordinate. The values of the coordinates at 5\% ammonia solution concentration increased as the temperature increased. Nevertheless, they decreased at the higher concentration of $10 \%$. The colour of the samples treated with a 5\% aqueous ammonia solution became redder and yellower as the process temperature rose, whereas, at the concentration of $10 \%$, it was the reverse; i.e., as the temperature rose, the amount of reddening and yellowing was smaller. Miklečić et al. (2012) also detected that the change of the $a^{*}$ coordinate was smaller than the $b^{*}$ coordinate. According to Miklečić et al. (2012), the $a^{*}$ for the oak wood modified with fuming ammonia decreased from 7.5 to 6.7. For maple and spruce, the $a^{*}$ increased, whereas for larch, the $a^{*}$ did not change. The $b^{*}$ for oak and larch wood decreased 8.6 and 6.7 units, respectively. For the maple and spruce wood, the $b^{*}$ value increased 5 and 4.1 units, respectively.

Colour saturation, as described by the $C^{*}$ coordinate value, decreased due to wood modification with ammonia. For the Robinia wood, the $C^{*}$ value dropped from 25.5 to the range 7.1 to 9.7, whereas for the oak wood, it dropped from 24.0 to the range 9.2 to 11.4. The $C^{*}$ parameter provided information about colour purity, which indicated that the samples treated with the $5 \%$ aqueous ammonia solution had higher colour saturation values as the process temperature rose, which indicated that their colour became more vivid. After $10 \%$ aqueous ammonia solution treatment, the colour saturation decreased as the process temperature rose. 
The colour angle, $h$, was $72.8^{\circ}$ to $73.7^{\circ}$ prior to the process treatment for Robinia and oak. After the modification, the $h$ for the Robinia wood dropped to the range 56.9 to $59.4^{\circ}$, and for the oak wood, it dropped to the range $66.0^{\circ}$ to $71.5^{\circ}$. The $h$ value fell as the process temperature increased, regardless of the applied ammonia concentration.

The $\Delta L^{*}$ values presented in Table 4 showed a certain similarity to the changes in the $L^{*}$ parameter. At $5 \%$ ammonia solution concentration, its value increased as the process temperature rose (i.e., $\Delta L^{*}$ for the Robinia was -37.2 to -35.1 units, and for the oak, it was -30.4 to -29.5 units); however, $\Delta L^{*}$ fell at $10 \%$ concentration (i.e., $\Delta L^{*}$ for the Robinia was -36.0 to -37.2 units, and for the oak it was -24.3 to -30.2 units). Weigl et al. (2012) concluded that the $\Delta L^{*}$ value for the oak wood following the modification with ammonia amounted to -22 units. Miklečić et al. (2012) reported that $\Delta L^{*}$ was a parameter that had the most the complete change of $\Delta E^{*}$ in the samples' colour.

Table 4. Colour Changes of Robinia pseudoacacia and Quercus Wood Under the Influence of Modification with Vapors of Ammonia Solutions

\begin{tabular}{|c|c|c|c|c|c|c|}
\hline \multirow{2}{*}{$\begin{array}{l}\text { Wood } \\
\text { Species }\end{array}$} & \multicolumn{2}{|c|}{ Densification Parameters } & \multicolumn{4}{|c|}{ Colour Coordinates } \\
\hline & $\begin{array}{c}\text { Temperature } \\
\left({ }^{\circ} \mathrm{C}\right)\end{array}$ & $\begin{array}{c}\text { Concentration } \\
(\%)\end{array}$ & $\Delta L^{*}$ & $\Delta a^{*}$ & $\Delta \boldsymbol{b}^{\star}$ & $\Delta E$ \\
\hline \multirow{6}{*}{ Robinia } & 120 & 5 & $\begin{array}{l}-37.15 \\
(0.73)^{\mathrm{B}}\end{array}$ & $\begin{array}{c}-2.60 \\
(0.42)^{\text {в }}\end{array}$ & $\begin{array}{l}-19.08 \\
(0.72)^{B}\end{array}$ & $\begin{array}{c}41.84 \\
(1.00)^{A}\end{array}$ \\
\hline & 130 & 5 & $\begin{array}{c}-36.26 \\
(1.71)^{A B}\end{array}$ & $\begin{array}{c}-2.06 \\
(0.79)^{\mathrm{B}}\end{array}$ & $\begin{array}{c}-18.20 \\
(1.67)^{\mathrm{B}}\end{array}$ & $\begin{array}{c}40.63 \\
(2.30) A B\end{array}$ \\
\hline & 140 & 5 & $\begin{array}{l}-35.08 \\
(1.29)^{A}\end{array}$ & $\begin{array}{c}-1.32 \\
(0.56)^{A}\end{array}$ & $\begin{array}{c}-16.97 \\
(1.33)^{A}\end{array}$ & $\begin{array}{c}39.00 \\
(1.74)^{B}\end{array}$ \\
\hline & 120 & 10 & $\begin{array}{c}-35.96 \\
(0.98) A B\end{array}$ & $\begin{array}{c}-2.09 \\
(0.41)^{\mathrm{B}}\end{array}$ & $\begin{array}{c}-18.05 \\
(0.94)^{A} \\
\end{array}$ & $\begin{array}{c}40.29 \\
(1.30) A B\end{array}$ \\
\hline & 130 & 10 & $\begin{array}{c}-36.08 \\
(1.89) A B\end{array}$ & $\begin{array}{c}-2.24 \\
(0.77)^{\text {в }}\end{array}$ & $\begin{array}{c}-18.42 \\
(1.68)^{\mathrm{B}}\end{array}$ & $\begin{array}{c}40.58 \\
(2.48) A B\end{array}$ \\
\hline & 140 & 10 & $\begin{array}{l}-37.22 \\
(1.07)^{B}\end{array}$ & $\begin{array}{c}-2.44 \\
(0.40)^{\mathrm{B}}\end{array}$ & $\begin{array}{l}-19.16 \\
(0.93)^{B}\end{array}$ & $\begin{array}{c}41.94 \\
(1.33)^{A}\end{array}$ \\
\hline \multicolumn{3}{|c|}{$\mathrm{LSD}_{0.05}$} & 1.27 & 0.55 & 1.2 & 1.68 \\
\hline \multirow{6}{*}{ Quercus } & 120 & 5 & $\begin{array}{l}-30.35 \\
(0.74)^{\text {B }}\end{array}$ & $\begin{array}{c}-3.37 \\
(0.28) \mathrm{CD}\end{array}$ & $\begin{array}{c}-13.19 \\
(0.69)^{C}\end{array}$ & $\begin{array}{c}33.27 \\
(0.88)^{A}\end{array}$ \\
\hline & 130 & 5 & $\begin{array}{l}-28.21 \\
(1.76)^{\mathrm{B}}\end{array}$ & $\begin{array}{c}-2.81 \\
(0.36)^{A B}\end{array}$ & $\begin{array}{c}-11.57 \\
(1.31) A B\end{array}$ & $\begin{array}{c}30.62 \\
(2.12)^{A}\end{array}$ \\
\hline & 140 & 5 & $\begin{array}{l}-29.52 \\
(1.17)^{B}\end{array}$ & $\begin{array}{c}-2.59 \\
(0.25)^{A}\end{array}$ & $\begin{array}{c}-12.15 \\
(0.77)^{A-C}\end{array}$ & $\begin{array}{c}32.03 \\
(1.38)^{A}\end{array}$ \\
\hline & 120 & 10 & $\begin{array}{l}-24.32 \\
(7.36)^{A}\end{array}$ & $\begin{array}{c}-3.41 \\
(0.38)^{D}\end{array}$ & $\begin{array}{l}-10.81 \\
(3.07)^{A}\end{array}$ & $\begin{array}{c}26.85 \\
(7.90)^{\mathrm{B}}\end{array}$ \\
\hline & 130 & 10 & $\begin{array}{c}-29.80 \\
(1.80)^{B}\end{array}$ & $\begin{array}{c}-3.00 \\
(0.43)^{\mathrm{BC}}\end{array}$ & $\begin{array}{c}-12.62 \\
(1.28) \mathrm{BC}\end{array}$ & $\begin{array}{l}32.50 \\
(2.17)^{\mathrm{A}}\end{array}$ \\
\hline & 140 & 10 & $\begin{array}{l}-30.17 \\
(1.38)^{\mathrm{B}}\end{array}$ & $\begin{array}{c}-2.90 \\
(0.70) \mathrm{AB}\end{array}$ & $\begin{array}{c}-12.74 \\
(1.29) \mathrm{BC}\end{array}$ & $\begin{array}{c}32.89 \\
(1.80)^{A}\end{array}$ \\
\hline \multicolumn{3}{|c|}{$\mathrm{LSD}_{0.05}$} & 3.1 & 0.4 & 1.52 & 3.41 \\
\hline
\end{tabular}

The $\Delta a^{*}$ parameter changes, i.e. the red and green differences, depended on the wood species (with the Robinia from -1.3 to 2.6 units, and with the oak from 2.6 to -3.4 units). The colour of all the samples due to the modification became less red and more green. The Robinia wood treated with 5\% aqueous ammonia solution at the lowest temperature of $120{ }^{\circ} \mathrm{C}$ obtained the least green colour, whereas the oak wood treated with 
$10 \%$ aqueous ammonia solution at the temperature of $120{ }^{\circ} \mathrm{C}$ underwent the greatest discolouration. It was concluded that the wood colour became greener as the process temperature increased. The only exceptions were the Robinia wood samples treated with a $10 \%$ ammonia solution, whose colour became less green and more red as the temperature rose. According to the literature, the $\Delta a^{*}$ for oak wood after treatment with ammonia amounted to -2 unit (Weigl et al. 2012). The negative values of the $\Delta a^{*}$ parameter after the modification with ammonia were also observed by Miklečić et al. (2012).

The yellow and blue $\left(\Delta b^{*}\right)$ chromatic difference was greater than the red and green $\left(\Delta a^{*}\right)$ difference. For the Robinia, the $\Delta b^{*}$ was from -17.0 to -19.2 units, and for the oak, it was from -10.8 to -13.2 units. The recorded $\Delta b^{*}$ alterations indicated that the sample colour changed toward the more blue direction due to wood modifications. The Robinia and oak wood samples treated with $5 \%$ aqueous ammonia solution became less blue as the temperature rose. In contrast, the woods modified with $10 \%$ solution had a more blue hue as the temperature rose. Miklečić et al. (2012) and Weigl et al. (2012) also concluded that the $\Delta b^{*}$ alteration was greater than the $\Delta a^{*}$ alteration. According to Miklečić et al. (2012), the $\Delta b^{*}$ changed to a greater extent for the oak and larch wood than for the maple and spruce wood. Weigl et al. (2012) observed a $\Delta b^{*}$ change for the oak wood at the level of 8 units, and for the spruce and pine wood of -1 and -10 units, respectively.

The total colour change, $\Delta E$, of the investigated samples ranged from 26.8 to 41.9 units. The lower discolouration degree was observed for the oak. The parameter for oak fluctuated between 26.8 and 33.3 units. However, for the Robinia it ranged from 39.0 to 41.9 units. The slightest colour change was recorded for the oak wood treated with $10 \%$ aqueous ammonia solution at a temperature of $120{ }^{\circ} \mathrm{C}$, whereas the greatest colour change was for the Robinia modified with the $10 \%$ solution at the highest temperature $\left(140{ }^{\circ} \mathrm{C}\right)$. It can be stated that both the Robinia and oak samples treated with 5\% aqueous ammonia solution obtained a lower degree of discolouration as the process temperature increased. However, the samples modified with $10 \%$ aqueous ammonia solution had a higher degree of discolouration as the temperature rose. Miklečić et al. (2012) came to the conclusion that the most susceptible wood from the investigated ones (i.e., oak, maple, spruce, and alder) to ammonia fuming was oak. The oak wood reacted with ammonia for the shortest period of time. A similar effect obtained during $24 \mathrm{~h}$ for the oak wood was obtained after 16 days of the modification with ammonia fuming for the remaining species.

\section{Dependence Between Colour Parameters}

Table 5 presents the regression equations describing the relationships between the analysed colour parameters (i.e., $L^{*}, a^{*}, b^{*}, h, C^{*}$, and $\Delta E$ ) and the coefficient of determination $\left(\mathrm{R}^{2}\right)$ values. For both investigated wood species, high $\mathrm{R}^{2}$ values, which revealed a good dependence, were noticed between $b^{*}$ chromatic coordinate and $L^{*}$ luminosity, $C^{*}$ saturation and $L^{*}$ luminosity, and $C^{*}$ saturation and yellow and blue $b^{*}$ coordinate, as well as between $\Delta b^{*}$ and $\Delta E$ difference and $L^{*}$ parameter. Additionally, the Robinia wood showed strong dependence between the red to green $a^{*}$ coordinate and the $\Delta a^{*}$ difference and $L^{*}$ coordinate, whereas for oak wood, it was between the $h$ angle and the $L^{*}$ coordinate. The $\mathrm{R}^{2}$ values for the features (variables) ranged from 0.7033 to 0.9967 . However, there was a weak dependence determined between the $h$ angle and coordinate $a^{*}$. Moreover, for oak wood, it was also observed between the colour saturation, $C^{*}$, and the red to green coordinate, $a^{*}$, as well as between $\Delta a^{*}$ and $L^{*}$. 


\section{Forecasting Models of Wood Discolouration with Ammonia}

The regression analysis presented the dependence of the investigated features (variables) from the process variables, i.e., aqueous ammonia solution concentration and temperature, as well as interactions between them.

Table 5. Regression Equations of Colour Parameters $\left(L^{*}, a^{*}, b^{*}, h, C^{*}\right.$, and $\left.\Delta E\right)$ and $\mathrm{R}^{2}$

\begin{tabular}{|c|c|c|}
\hline $\begin{array}{c}\text { Wood } \\
\text { Species }\end{array}$ & Fitted Function & $\mathrm{R}^{2}$ \\
\hline \multirow{11}{*}{ Robinia } & $a^{*}=-0.0232 L^{* 2}+1.8849 L^{*}-31.813$ & 0.8396 \\
\hline & $b^{*}=0.9327 L^{*}-21.855$ & 0.9371 \\
\hline & $h=0.0241 L^{* 2}-0.7531 L^{*}+58.756$ & 0.5781 \\
\hline & $h=0.1763 a^{* 2}-0.414 a^{*}+57.04$ & 0.2852 \\
\hline & $h=0.0119 b^{\star 2}+0.5715 b^{*}+53.951$ & 0.5222 \\
\hline & $C^{\star}=31.965 \ln \left(L^{*}\right)-101.47$ & 0.925 \\
\hline & $C^{*}=1.5877 a^{* 1.132}$ & 0.964 \\
\hline & $C^{\star}=-0.0102 b^{\star 2}+1.2506 b^{*}-0.0368$ & 0.9958 \\
\hline & $\Delta a^{*}=-0.0247 L^{* 2}+1.9803 L^{*}-39.648$ & 0.8384 \\
\hline & $\Delta b^{*}=-0.0106 L^{* 2}+1.5976 L^{*}-57.472$ & 0.9289 \\
\hline & $\Delta E=113 \mathrm{e}^{-0.033 L^{*}}$ & 0.9773 \\
\hline \multirow{11}{*}{ Quercus } & $a^{*}=-0.0102 L^{* 2}+0.8939 L^{*}-15.068$ & 0.2281 \\
\hline & $b^{*}=-0.0172 L^{* 2}+1.895 L^{*}-36.797$ & 0.9155 \\
\hline & $h=-0.0048 L^{* 2}+0.9869 L^{*}+37.682$ & 0.7033 \\
\hline & $h=73.259 \mathrm{e}^{-0.021 a^{*}}$ & 0.082 \\
\hline & $h=1.031 b^{\star}+57.726$ & 0.4719 \\
\hline & $C^{\star}=-0.0192 L^{* 2}+2.0532 L^{*}-39.066$ & 0.8727 \\
\hline & $C^{\star}=3.7167 a^{\star 0.7455}$ & 0.3812 \\
\hline & $C^{\star}=-0.0156 b^{\star 2}+1.334 b^{\star}-0.9434$ & 0.9945 \\
\hline & $\Delta a^{*}=-0.0102 L^{* 2}+0.893 L^{*}-21.944$ & 0.2277 \\
\hline & $\Delta b^{*}=-0.0172 L^{* 2}+1.8956 L^{*}-58.493$ & 0.9154 \\
\hline & $\Delta E=0.0079 L^{* 2}-1.751 L^{*}+85.219$ & 0.9967 \\
\hline
\end{tabular}

A multiple regression analysis using the estimation of the smallest quadrants was applied to calculate modelling coefficients for the wood discolouration degree under the ammonia treatment. The following model was used to determine colour parameters,

$$
\text { Colour parameter }=k_{0}+k_{1} C_{0}+k_{2} T+k_{3} C_{0} T
$$

where $C_{0}$ is the ammonia concentration $(\%), T$ is the temperature $\left({ }^{\circ} \mathrm{C}\right)$, and $k_{0}, k 1, k 2$, and $k_{3}$ are the constants (coefficients).

The modelling coefficients for the investigated wood species are presented in Table 6. Analysing the obtained results, it can be concluded that for the two investigated wood species, the process temperature did not affect the $h$ angle, and $k_{0}$ constant did not affect $L^{*}$. 
For the oak wood, the $k_{0}$ did not influence the $L^{*}, a^{*}$, and $b^{*}$ coordinates nor the $C$ value. Moreover, there was no evidence of an aqueous ammonia solution concentration influence on $a^{*}$ and $\Delta a^{*}$ values, as well as the interactions between ammonia concentration and the process temperature for the oak wood. The forecasting models of the wood discolouration degree had $\mathrm{R}^{2}$ values that ranged from 0.09 to 0.44 , which did not indicate a strong dependence between the variables and the process reaction.

Table 6. Regression Results of Between Colour Parameters and Parameters of the Modification Process

\begin{tabular}{|c|c|c|c|c|c|c|}
\hline $\begin{array}{c}\text { Wood } \\
\text { Species }\end{array}$ & $\begin{array}{c}\text { Colour } \\
\text { Parameter }\end{array}$ & $k_{0}$ & $k_{1}\left(C_{0}\right)$ & $k_{2}(T)$ & $k_{3}\left(C_{0} T\right)$ & $\mathbf{R}^{2}$ \\
\hline \multirow{9}{*}{ Robinia } & $L^{*}$ & -4.83 & $4.48^{* \star \star}$ & $0.2783^{* * *}$ & $-0.035^{\star \star \star}$ & 0.22 \\
\hline & $a^{*}$ & $-14.45^{\star \star \star}$ & $2.10^{\star \star \star}$ & $0.147^{\star \star \star}$ & $-0.017^{\star \star \star}$ & 0.32 \\
\hline & $b^{*}$ & $-27.79^{\star *}$ & $4.25^{\star \star \star}$ & $0.273^{\star * \star}$ & $-0.034^{\star \star *}$ & 0.25 \\
\hline & $h$ & $44.40^{\star \star \star}$ & $3.04^{* *}$ & 0.112 & $-0.024^{* *}$ & 0.22 \\
\hline & $C^{*}$ & $-31.48^{* *}$ & $4.77^{\star \star \star}$ & $0.311^{* * *}$ & $-0.038^{* * *}$ & 0.27 \\
\hline & $\Delta L^{*}$ & $-70.98^{* \star *}$ & $4.27^{\star \star \star}$ & $0.270^{* * *}$ & $-0.033^{* * *}$ & 0.19 \\
\hline & $\Delta a^{*}$ & $-20.63^{\star \star \star}$ & $2.064^{\star * *}$ & $0.145^{\star \star *}$ & $-0.016^{\star \star *}$ & 0.31 \\
\hline & $\Delta b^{*}$ & $-52.35^{\star \star *}$ & $4.10^{\star \star \star}$ & $0.267^{* * *}$ & $-0.032^{* \star *}$ & 0.23 \\
\hline & $\Delta E$ & $87.7^{\star \star \star}$ & $-5.75^{\star \star \star}$ & $-0.367^{\star * *}$ & $0.045^{\star \star *}$ & 0.21 \\
\hline \multirow{9}{*}{ Oak } & $L^{*}$ & -13.7 & $8.93^{\star *}$ & $0.375^{*}$ & $-0.067^{* * *}$ & 0.19 \\
\hline & $a^{*}$ & -2.61 & 0.307 & $0.052^{*}$ & -0.003 & 0.28 \\
\hline & $b^{*}$ & -17.0 & $3.92^{\star *}$ & $0.201^{*}$ & $-0.030^{* *}$ & 0.09 \\
\hline & $h$ & $52.6^{* * *}$ & $5.15^{\star \star}$ & 0.103 & $-0.038^{\star *}$ & 0.44 \\
\hline & $C^{*}$ & -17.1 & $3.82^{*}$ & $0.209^{*}$ & $-0.029^{*}$ & 0.07 \\
\hline & $\Delta L^{*}$ & $-79.4^{* *}$ & $8.93^{* *}$ & $0.375^{*}$ & $-0.067^{* *}$ & 0.19 \\
\hline & $\Delta a^{*}$ & $-9.51^{* *}$ & 0.307 & $0.052^{*}$ & -0.003 & 0.28 \\
\hline & $\Delta b^{*}$ & $-38.7^{* *}$ & $3.92^{* *}$ & $0.201^{*}$ & $-0.030^{* *}$ & 0.09 \\
\hline & $\Delta E$ & $88.6^{\star *}$ & $-9.70^{* *}$ & $-0.426^{*}$ & $0.073^{\star *}$ & 0.17 \\
\hline
\end{tabular}

\section{Changes in Chemical Structure}

The FTIR technique was applied for the detection of changes in structure in Robinia and oak wood following the treatment with vapors of ammonia solutions. The FTIR spectra are shown in Figs. 1 and 2. It was noticed that the spectra of all samples did not show significant differences. Only slight changes were visible between the spectra acquired for the reference Robinia and oak wood samples and the samples treated with with vapors of ammonia solutions. The bands in the region of 2000 to $800 \mathrm{~cm}^{-1}$ were affected by the contribution of all wood components. Only one band could not be attributed to the wood components, which was the band at $1656 \mathrm{~cm}^{-1}$. The presence of this band was found only in the spectra of Robinia and oak samples modified with a $10 \%$ mixture of water vapour and ammonia at $120^{\circ} \mathrm{C}$ and at $130{ }^{\circ} \mathrm{C}$. According to the literature (Owen and Pawlak 1989; Pawlak and Pawlak 1997; Miklečić et al. 2012), this occurrence is associated with the presence of amines and imines. Miklečić et al. (2012) investigated oak and maple wood after modification with ammonia and discovered a new absorption band at $1650 \mathrm{~cm}^{-1}$, which results from the reaction of ammonia with carboxyl ester groups to form amides. 


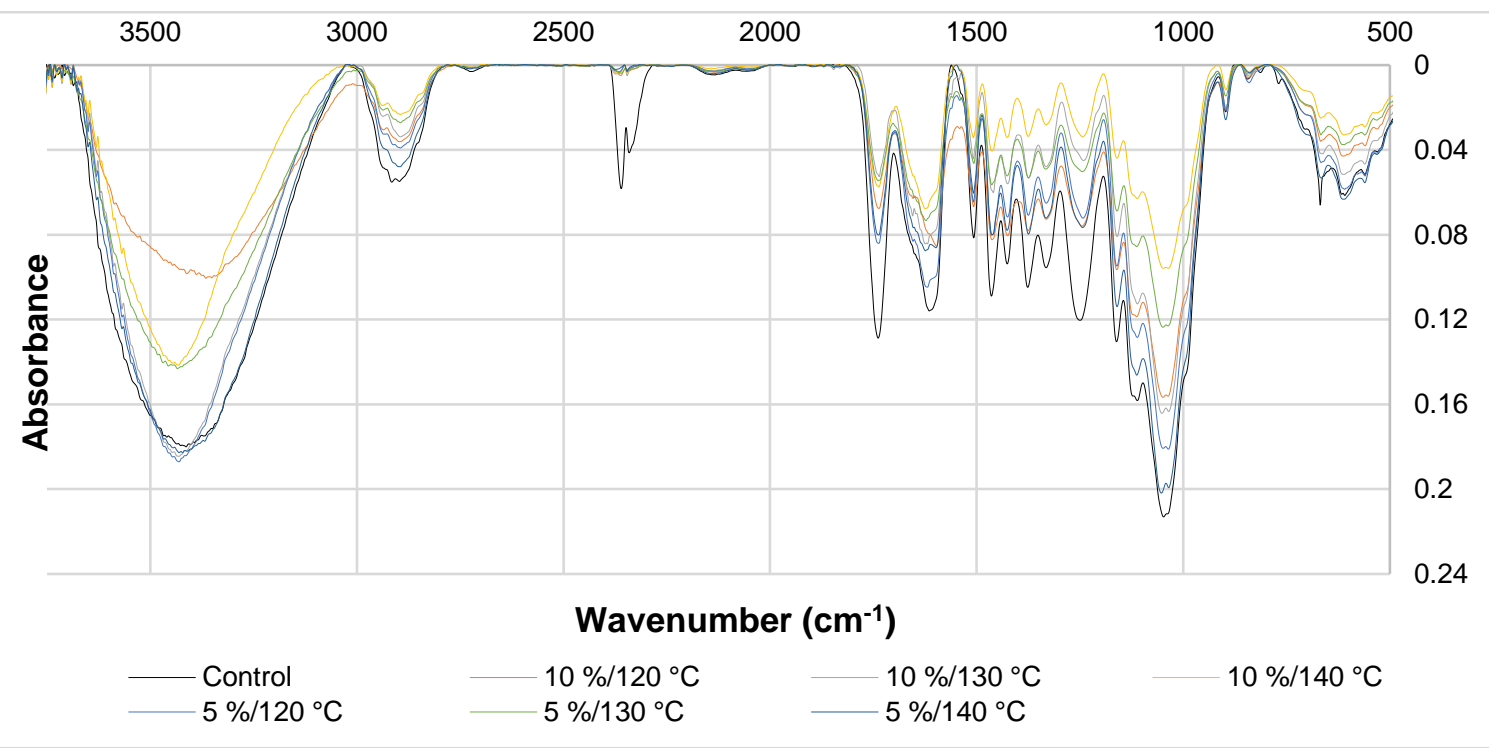

Fig. 1. FTIR spectra of Robinia pseudoacacia wood after the treatment with ammonia

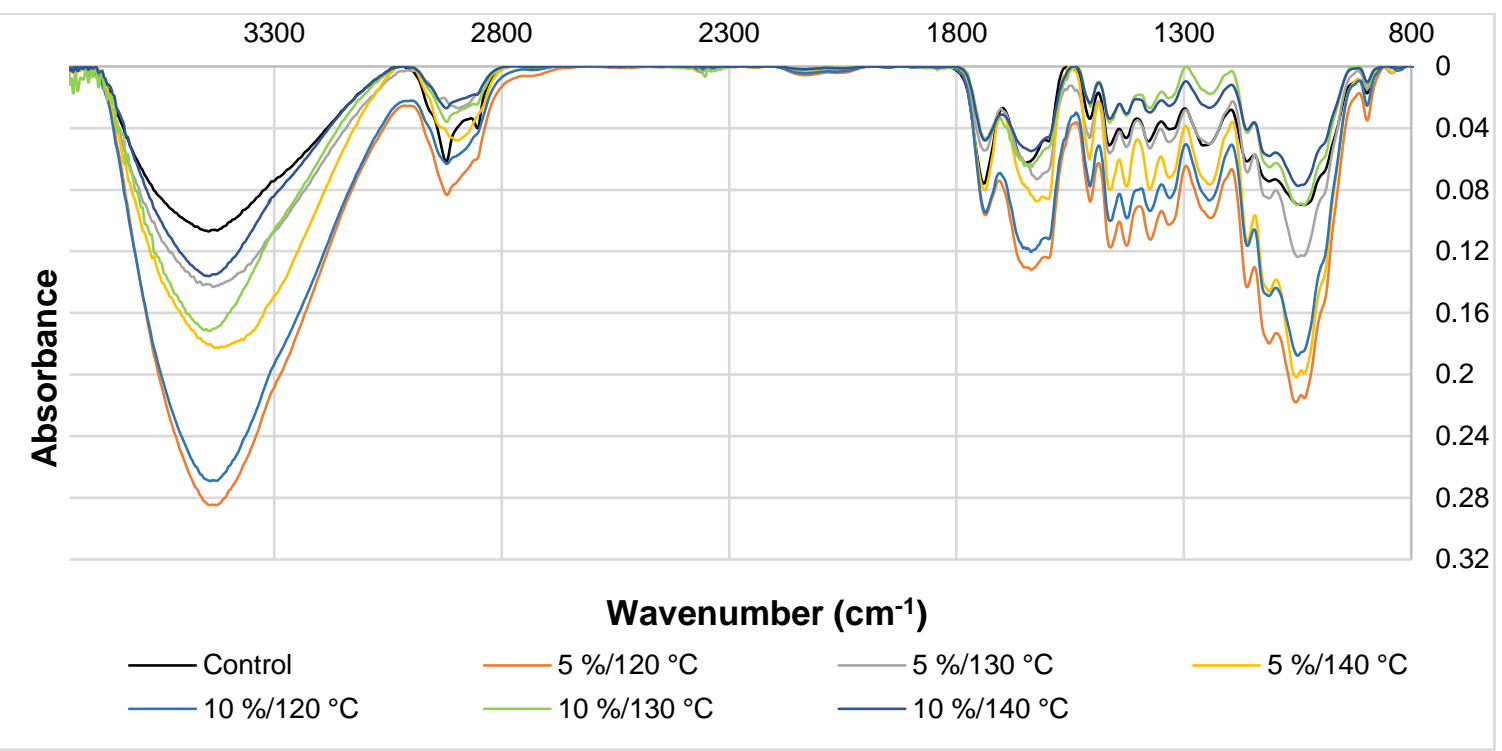

Fig. 2. FTIR spectra of oak wood after the treatment with ammonia

To better understand the changes that occurred in the Robinia and oak wood during the applied treatment, some ratios were calculated between areas of carbohydrate- and lignin-related absorption bands $\left(1510 \mathrm{~cm}^{-1} / 1730 \mathrm{~cm}^{-1}\right.$ and $\left.1510 \mathrm{~cm}^{-1} / 897 \mathrm{~cm}^{-1}\right)$. The results are presented in Fig. 3. For oak wood, the increases with the ratios of areas $1510 \mathrm{~cm}^{-1} / 1730$ $\mathrm{cm}^{-1}$ and $1510 \mathrm{~cm}^{-1} / 897 \mathrm{~cm}^{-1}$ were observed with the ammonia treatment. This indicated that the contribution of lignin to the IR absorption band increased with respect to the carbohydrates (hemicelluloses and cellulose). This phenomenon highlighted the loss of all carbohydrates during the modification of the wood, which was probably due to their depolymerisation. For Robinia wood, the area ratio increase was only observed for 1510 $\mathrm{cm}^{-1} / 1730 \mathrm{~cm}^{-1}$. This indicated that in Robinia wood, only the hemicelluloses underwent depolimerization. This observation is in agreement with the results reported by Bariska (1969) and Miklečić et al. (2012). In contrast, the decrease in the ratio of $1510 \mathrm{~cm}^{-1} / 879$ 
$\mathrm{cm}^{-1}$ indicated a decrease in lignin in relation to cellulose. This could indicate that that Robinia lignin is less stable than cellulose. Additionally, it could mean that comparable species underwent other chemical changes in the range of main constituents during the ammonia treatment. The FTIR was the only method that showed the changes, specifically to the hemicelluloses and cellulose. In fact, the ratio between the areas of the absorption bands at $1730 \mathrm{~cm}^{-1}$ and $897 \mathrm{~cm}^{-1}$, which corresponded to hemicelluloses and cellulose, respectively, decreased during the treatment with ammonia. This highlighted the slower decay of the cellulose with respect to the hemicelluloses in the analysed samples during the ammonia treatment. The hemicelluloses, as easier hydrolysable polysaccharides, degraded first and faster. However, when comparing the two wood species, other trends were observed. For Robinia, the observed decrease was significant and larger as the treatment temperature increased, whereas for oak, a clear trend was difficult to detect. These differences confirmed that the degradation of wood in the compared species proceeded in different ways.

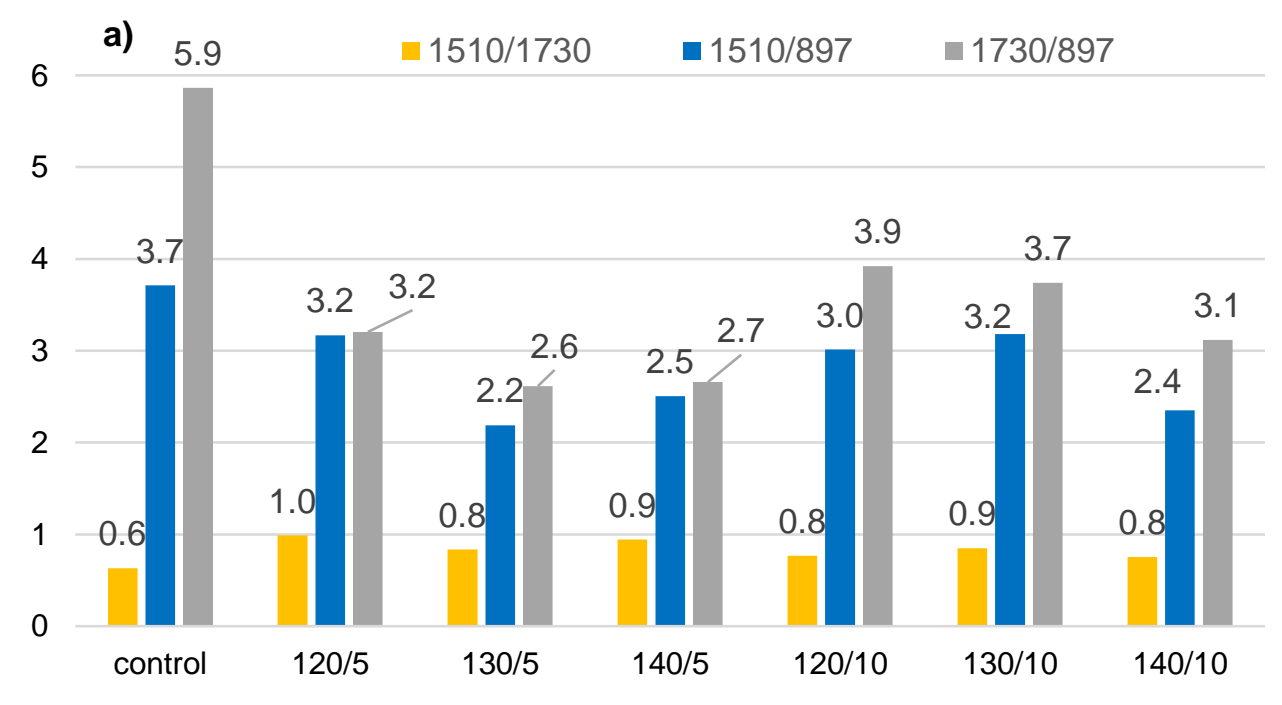

b)

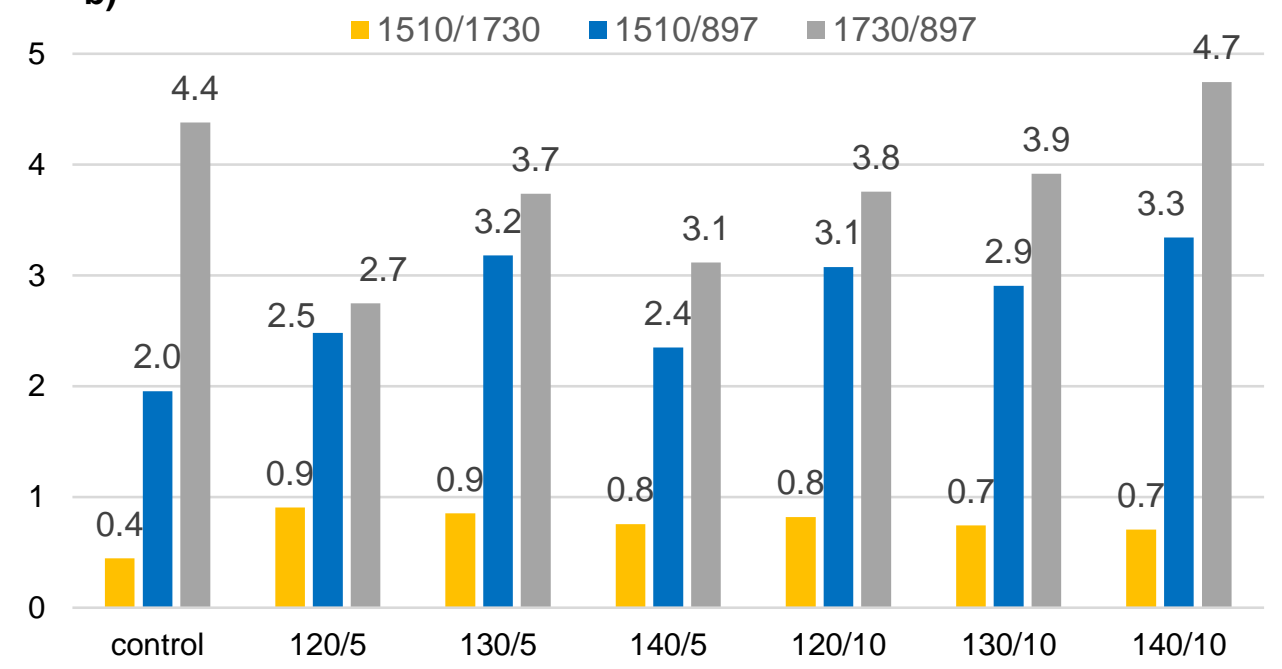

Fig. 3. Ratio between absorption areas of selected FTIR absorption bands $\left(\mathrm{cm}^{-1}\right)$ for different temperature $\left({ }^{\circ} \mathrm{C}\right) /$ ammonia concentration (\%): a) Robinia pseudoacacia and b) oak 
The larger changes in the structure of Robinia lignin caused by the modification process may have contributed to its more intense discoloration compared to oak wood. The measurements of color parameters showed that oak wood was less discolored than Robinia wood. Therefore, the results regarding the observed color changes of the tested species are compatible with the FTIR analysis.

The occurring degradation of the wood substance during modification is also confirmed by the recorded mass losses of wood.

\section{CONCLUSIONS}

1. Modification of Robinia pseudoacacia and Quercus wood with a vapors of aqueous ammonia solution of 5 and $10 \%$ concentration in the temperatures of 120,130, and 140 ${ }^{\circ} \mathrm{C}$ caused discoloration of the tested wood species.

2. The complete change of colour, $\Delta E$, for the Robinia wood ranged from 39.0 to 41.9 , and for the oak was smaller and ranged from 26.8 to 33.3.

3. The oak wood was discolored to the greatest degree due to modification with a $5 \%$ aqueous ammonia solution at $120{ }^{\circ} \mathrm{C}$ and to the least degree with a $10 \%$ aqueous ammonia at $120{ }^{\circ} \mathrm{C}$. In turn, the Robinia wood was discolored to the greatest degree under the influence of a $10 \%$ aqueous ammonia solution at $140{ }^{\circ} \mathrm{C}$, and to the least degree under the influence of a $5 \%$ aqueous ammonia solution in $140{ }^{\circ} \mathrm{C}$.

4. The $L^{*}$ and $b^{*}$ coordinates influenced the net color change, as represented by $\Delta E$, the most.

5. The colour of the samples following the modification became appreciably darker, as well as less red and yellow.

6. The analysis of variance showed that in most cases neither aqueous ammonia solution concentration nor the process temperature individually caused significant differences in wood colouration. However, the concentration-temperature interaction was significant.

7. The FTIR analysis showed that the Robinia and oak wood treated with the mixture of aqueous ammonia vapours at the concentration of 5 or $10 \%$ at temperatures between 120 to $140{ }^{\circ} \mathrm{C}$ caused changes to the wood structure. Moreover, these changes depended on the wood species. With oak wood, the amounts of cellulose and hemicelluloses decreased, and with Robinia wood, only the amount of hemicelluloses decreased. Changes to the $1510 \mathrm{~cm}^{-1} / 879 \mathrm{~cm}^{-1}$ ratio may indicate a decrease in lignin content relative to cellulose content. These results correlated with the color change. Greater changes to the structure of lignin occurred with Robinia, which underwent greater discoloration.

\section{ACKNOWLEDGMENTS}

This research was partially financed within the framework of the Ministry of Science and Higher Education programme "Regional Initiative of Excellence" during the years of 2019 and 2022 (Project No. 005/RID/2018/19). 


\section{REFERENCES CITED}

Bariska, M. (1969). "Plastifizierung des Holzes mit Ammoniak in Theorie und Praxis," Holz-Zentralblatt 95(85), 1309-1311.

Čermák, P., and Dejmal, A. (2013). "The effect of heat and ammonia treatment on colour response of oak wood (Quercus robur) and comparison of some physical and mechanical properties," Maderas. Ciencia y Tecnología 15(3), 375-389. DOI: 10.4067/S0718-221X2013005000029

Kolář, T., and Rybníček, M. (2010). "Physical and mechanical properties of Subfossil Oak (Quercus, sp.) wood," Acta Universitatis Agriculturae et Silviculturae Mendelianae Brunensis 58(4), 123-134. DOI: 10.11118/actaun201058040123

Kučerová, V., Lagaňa, R., Výbohová, E., and Hýrošová, T. (2016). “The effect of chemical changes during heat treatment on the color and mechanical properties of fir wood," BioResources 11(4), 9079-9094. DOI: 10.15376/biores.11.4.9079-9094

Lao, W., Li, G., Zhou, Q., and Qin, T. (2014). "Quantitative analysis of biomass in three types of wood-plastic composites by FTIR spectroscopy," BioResources 9(4), 60736086. DOI: 10.15376/biores.9.4.6073-6086

Machová, D., Baar, J., Paschová, Z., Pařil, P., Křenková, J., and Kúdela, J. (2019). “Color changes and accelerated ageing in oak wood treated with ammonia gas and iron nanoparticles," European Journal of Wood and Wood Products 77(4), 705-716. DOI: 10.1007/s00107-019-01406-X

Mańkowski, P., Kozakiewicz, P., and Drożdżek, M. (2016). "The selected properties of fossil oak wood from Medieval Burgh in Płońsk," Wood Research 61(2), 287-298.

Miklečić, J., Španić, N., and Jirouš-Rajković, V. (2012). "Wood color changes by ammonia fuming," BioResources 7(3), 3767-3778. DOI: 10.15376/biores.7.3.37673778

Minelga, D., Ukvalbergienė, K., Baltrušaitis, A., and Balčiūnas, G. (2013). “Adhesion properties between polyvinyl acetate dispersion and ammonia modified oak wood," Materials Science 19(2), 164-168. DOI: 10.5755/j01.ms.19.2.4433

Owen, N. L., and Pawlak, Z. (1989). "An infrared study of the effect of liquid ammonia on wood surfaces," Journal of Molecular Structure 198, 435-449. DOI: 10.1016/0022-2860(89)80055-9

Pawlak, Z., and Pawlak A. S. (1997). "A review of infrared spectra from wood and wood components following treatment with liquid ammonia and solvated electrons in liquid ammonia," Applied Spectroscopy Reviews 32(4), 349-383. DOI: 10.1080/05704929708003319

Pařil, P., Brabec, M., Maňák, O., Rousek, R., Rademacher, P., Čermák, P., and Dejmal, A. (2014). "Comparison of selected physical and mechanical properties of densified beech wood plasticized by ammonia and saturated steam," European Journal of Wood and Wood Products 72, 583-591. DOI: 10.1007/s00107-014-0814-8

Popescu, C.-M., Singurel, G., Vasile, C., Argyropoulos, D. S., and Willfor, S. (2007). "Spectral characterization of eucalyptus wood," Applied Spectroscopy 61(11), 11681177. DOI: $10.1366 / 000370207782597076$

Rosca, I., Pühringer, R., Schmidt, H., and Tanczos, I. (2002). "New aspects in studying and application of ammonia treatment of softwood," in: Wood Structure and Properties '02: Proceedings of the 4th IUFRO Symposium Wood Structure and Properties, J. Kúdela, S. Kurjatko, and J. Kúdela (eds.), Zvolen, Slovakia, pp. 127-129. 
Rousek, R., Rademacher, P., Brabec, M., Dejmal, A., Hornicek, S., Baar, J., and Sprdlik, V. (2015). "Beech wood modification with ammonia gas - Improved properties," Pro Ligno 11(4), 230-238.

Šprdlík, V., Brabec, M., Mihailović, S., and Rademacher, P. (2016). "Plasticity increase of beech veneer by steaming and gaseous ammonia treatment," Maderas. Ciencia y Tecnología 18(1), 91-98. DOI: 10.4067/S0718-221X2016005000009

Timar, M. C., Varodi, A., Hacibektasoglu, M., and Campean, M. (2016). "Color and FTIR analysis of chemical changes in beech wood (Fagus sylvatica L.) after light streaming and heat treatment in two different environments," BioResources 11(4), 8325-8343. DOI: 10.15376/biores.11.4.8325-8343

Tinkler, C. K. (1921). “" 'Fumed' oak and natural brown oak," Biochemical Journal 15(4), 477-486. DOI: $10.1042 / b j 0150477$

VSN International (2015). Genstat Reference Manual (Release 18), VSN International, Hemel Hempstead, UK.

Weigl, M., and Mülle, U. (2009). "On the mechanical stability of ammonia treated wood," in: Fourth European Conference on Wood Modification, F. Englund, C. A. S. Hill, H. Militz, and B. K. Segerholm (eds.), Stockholm, Sweden, pp. 483-486.

Weigl, M., Müller, U., Wimmer, R., and Hansmann, C. (2012). "Ammonia vs. thermally modified timber - Comparison of physical and mechanical properties," European Journal of Wood and Wood Products 70(1-3), 233-239. DOI: 10.1007/s00107-0110537-Z

Weigl, M., Pöckl, J., and Grabner, M. (2009). "Selected properties of gas phase ammonia treated wood," European Journal of Wood and Wood Products 67(1), 103-109. DOI: 10.1007/s00107-008-0301-1

Weigl, M., Pöckl, J., Müller, U., Pretzl, H., and Grabner, M. (2007). "UV-resistance of ammonia treated wood," in: Third European Conference on Wood Modification, C. A. S. Hill, D. Jones, H. Militz, and G. A. Ormondroyd (eds.), Bangor University, Gwynedd, Wales, pp. 209-212.

Xu, F., Yu, J., Tesso, T., Dowell, F., and Wang, D. (2013). "Qualitative and quantitative analysis of lignocellulosic biomass using infrared techniques: A mini-review," Applied Energy 104, 801-809. DOI: 10.1016/j.apenergy.2012.12.019

Zakrzewski, R. (2007). "Sposób przebarwiania drewna [The method of wood discoloration," Akademia Rolnicza w Poznaniu [Agricultural University of Poznan], Poland Patent No. PL195348 B1.

Article submitted: December 10, 2019; Peer review completed: April 10, 2020; Revised version received and accepted: June 2, 2020; Published: June 10, 2020.

DOI: $10.15376 /$ biores. 15.3.5812-5828 